\title{
Methylocystis rosea sp. nov., a novel methanotrophic bacterium from Arctic wetland soil, Svalbard, Norway $\left(78^{\circ} \mathrm{N}\right)$
}

\author{
Ingvild Wartiainen, ${ }^{1} \dagger$ Anne Grethe Hestnes, ${ }^{1}$ lan R. McDonald ${ }^{2}$ \\ and Mette M. Svenning ${ }^{1}$ \\ ${ }^{1}$ Department of Biology, Faculty of Science, University of Troms $\emptyset$, N-9037 Troms $\emptyset$, Norway \\ ${ }^{2}$ Department of Biological Sciences, University of Waikato, Private Bag 3105, Hamilton, \\ New Zealand
}

\begin{abstract}
A Gram-negative, rod-shaped, non-motile, non-spore-forming, pink-pigmented bacterium, SV97 ${ }^{\top}$, was isolated from a wetland soil near $\mathrm{Ny}$-Ålesund, Svalbard Islands, Norway $\left(78^{\circ} \mathrm{N}\right)$. On the basis of $16 \mathrm{~S}$ rRNA gene sequence similarity, strain SV9 $7^{\top}$ was shown to belong to the Alphaproteobacteria and was highly related to a number of non-characterized Methylocystis strains with GenBank accession nos AJ458507 and AJ458502 (100\%) and AF177299, AJ458510, AJ458467, AJ458471, AJ431384, AJ458475, AJ458484, AJ458501 and AJ458466 (99\%). The most closely related type strains were Methylocystis parvus $\mathrm{OBBP}^{\top}(97 \cdot 2 \%)$ and Methylocystis echinoides IMET $10491^{\top}(97 \%)$. The closest related recognized species within the genus Methylosinus was Methylosinus sporium NCIMB $11126^{\top}$ (96.0\% similarity). Chemotaxonomic and phenotypic data $\left(\mathrm{C}_{18: 1} \omega 8\right.$ as the major fatty acid, non-motile, no rosette formation) supported the affiliation of strain $\mathrm{SV} 97^{\top}$ to the genus Methylocystis. The results of DNA-DNA hybridization and physiological and biochemical tests allowed genotypic and phenotypic differentiation of strain SV9 $7^{\top}$ from the two recognized Methylocystis species. Strain $S V 97^{\top}$ therefore represents a novel species, for which the name Methylocystis rosea sp. nov. is proposed, with the type strain SV97 ${ }^{\top}$ $\left(=\right.$ DSM $17261^{\top}=$ ATCC BAA-1196 ${ }^{\top}$ ).
\end{abstract}

The type II methanotrophic bacteria consist of four genera, Methylocystis and Methylosinus (Bowman et al., 1993), Methylocella (Dedysh et al., 2000) and Methylocapsa (Dedysh et al., 2002). They are distinguished from type I methanotrophic bacteria by genetic and phenotypic features. Type II methanotrophs belong to the Alphaproteobacteria, assimilate formaldehyde by the serine pathway, have intracytoplasmic membranes aligned parallel to the cell wall (Methylocystis and Methylosinus), membrane vesicles packed in parallel on one side of the cell membrane (Methylocapsa) or a vesicular membrane system connected to the cytoplasmic membrane (Methylocella), and the major fatty acid is $\mathrm{C}_{18: 1} \omega 8 \mathrm{c}$

Published online ahead of print on 28 October 2005 as DOI 10.1099/ ijs.0.63912-0.

tPresent address: Svanhovd Miljøsenter, N-9925 Svanvik, Norway.

Abbreviation: $\mathrm{PHB}$, poly- $\beta$-hydroxybutyrate.

The GenBank/EMBL/DDBJ accession numbers for the 16S rRNA, $p m o A$ and nifH gene sequences of Methylocystis rosea SV97 ${ }^{\top}$ are AJ414656, AJ414657 and D0010107, respectively.

A chart showing the growth characteristics of Methylocystis rosea $\mathrm{SV} 7^{\top}$ at different temperatures and a detailed description of the methods used for fatty acid analysis are available as supplementary material in IJSEM Online.
(Methylocystis and Methylosinus) (Hanson \& Hanson, 1996) or $\mathrm{C}_{18: 1} \omega 7 c$ (Methylocella and Methylocapsa) (Dedysh et al., 2000, 2002). At present, the genus Methylocystis comprises two species with validly published names, Methylocystis parvus (Bowman et al., 1993; Whittenbury et al., 1970) and Methylocystis echinoides (Galchenko et al., 1977). However, a large number of strains designated as members of the genus Methylocystis has been isolated from several different environments (Dunfield et al., 2002; Heyer et al., 2002; Wise et al., 1999).

Strain $\mathrm{SV} 7^{\mathrm{T}}$ was isolated from a soil core collected from a high Arctic wetland near the Ny-Ålesund settlement $\left(78^{\circ} 56^{\prime}\right.$ $\left.\mathrm{N} 11^{\circ} 53^{\prime} \mathrm{E}\right)$ on the Svalbard Islands, Norway, in July 1997. At the time of sampling, the soil had a $\mathrm{pH}$ of 6.4 and the temperature of the soil was $10{ }^{\circ} \mathrm{C}$ at the surface and $5{ }^{\circ} \mathrm{C}$ at $10 \mathrm{~cm}$ below the surface and the permafrost level was at $25 \mathrm{~cm}$. Methane emission from the same site was determined in July and September 1998 and in July and August 1999 and emission varied from 93 to $2801 \mu \mathrm{g} \mathrm{CH}_{4} \mathrm{~m}^{-2} \mathrm{~h}^{-1}$ (Høj et al., 2005).

After removal of the fresh vegetation layer, the upper $10 \mathrm{~cm}$ of the soil core was mixed and $2 \mathrm{~g}$ soil was added to $10 \mathrm{ml}$ nitrate mineral salt (NMS) medium (Whittenbury et al., 
$1970)$ at $\mathrm{pH} 6.8$ and shaken for $10 \mathrm{~min}$ at 200 r.p.m. After 10 min of sedimentation, $1 \mathrm{ml}$ supernatant was mixed with $9 \mathrm{ml}$ NMS medium in a $120 \mathrm{ml}$ serum bottle (Alltech) and then sealed with a rubber stopper and crimp cap. The gas atmosphere inside the bottle was enriched with methane by replacing $20 \mathrm{ml}$ air with $20 \mathrm{ml} \mathrm{CH} / \mathrm{CO}_{2}$ (95:5) mix. The bottle was incubated at $20^{\circ} \mathrm{C}$ and subcultured every 2-3 weeks ( $1 \mathrm{ml}$ culture to $9 \mathrm{ml}$ fresh NMS medium). After four or five subculturing steps in liquid media, bacteria were plated on NMS medium containing $1.5 \%$ noble agar (bacteriological agar type E; Biokar Diagnostics). The plates were incubated at $20{ }^{\circ} \mathrm{C}$ in sealed chambers containing approximately $35 \%$ methane in air. Colonies were picked and restreaked. Heterotrophic contamination was checked by streaking colonies on agar plates with rich medium, containing $0.5 \%$ tryptone, $0.25 \%$ yeast extract, $0.1 \%$ glucose and $2.0 \%$ agar. These plates were incubated at $20{ }^{\circ} \mathrm{C}$ without additional methane. The cultures were considered to be pure when only one cell type was observed under light microscopy and no growth on nutrient-rich medium or on NMS agar without methane was observed. Exospore formation was assayed by determining cell viability after heating 3week-old cultures to $80^{\circ} \mathrm{C}$ for $20 \mathrm{~min}$ and then observing microcolony formation on NMS agar after 2 weeks incubation with methane (Bowman et al., 1993). Cyst formation was assayed by the method of Vela \& Wyss (1964) and by light microscopy of 3-week-old cultures. The presence of poly- $\beta$-hydroxybutyrate $(\mathrm{PHB})$ inclusions was determined by staining with $0.03 \%(\mathrm{w} / \mathrm{v})$ Sudan black and $0.5 \%$ safranin (Gerhardt, 1981) and observing using phasecontrast microscopy. The presence of PHB was also confirmed by chemical analysis (Gerhardt, 1981). Tolerance of $\mathrm{NaCl}$ concentrations ranging from 0.01 to $1 \cdot 0 \%(\mathrm{w} / \mathrm{v})$ was determined with NMS agar cultures. Growth at $\mathrm{pH}$ range $5 \cdot 5-9 \cdot 0$ was determined in liquid cultures of NMS. The $\mathrm{pH}$ of the medium was adjusted with $\mathrm{NaOH}$ or $\mathrm{HCl}$. Growth on alternative carbon sources was determined on methanol concentrations ranging from $0 \cdot 1$ to $1 \cdot 0 \%(\mathrm{v} / \mathrm{v})$ and ethanol, formate, formamide, formaldehyde, glucose, sucrose, acetate, citrate and yeast extract, all at $0 \cdot 1 \%(\mathrm{v} / \mathrm{v})$, in liquid cultures of NMS. Ability to fix nitrogen was determined by growth on nitrate (NMS), ammonia (AMS) and nitrogenfree (NFMS) media (Auman et al., 2001). Possession of the soluble methane monooxygenase (sMMO) was tested for by using a colorimetric assay described by Brusseau et al. (1990), with modifications (Graham et al., 1992). The DNA $\mathrm{G}+\mathrm{C}$ content was determined by thermal denaturation using a spectrophotometer (Cary $4 \mathrm{E}$; Varian) at a heating rate of $0.5{ }^{\circ} \mathrm{C} \mathrm{min}^{-1}$. The DNA G $+\mathrm{C}$ content was calculated as described by Mandel et al. (1970). DNA-DNA hybridization

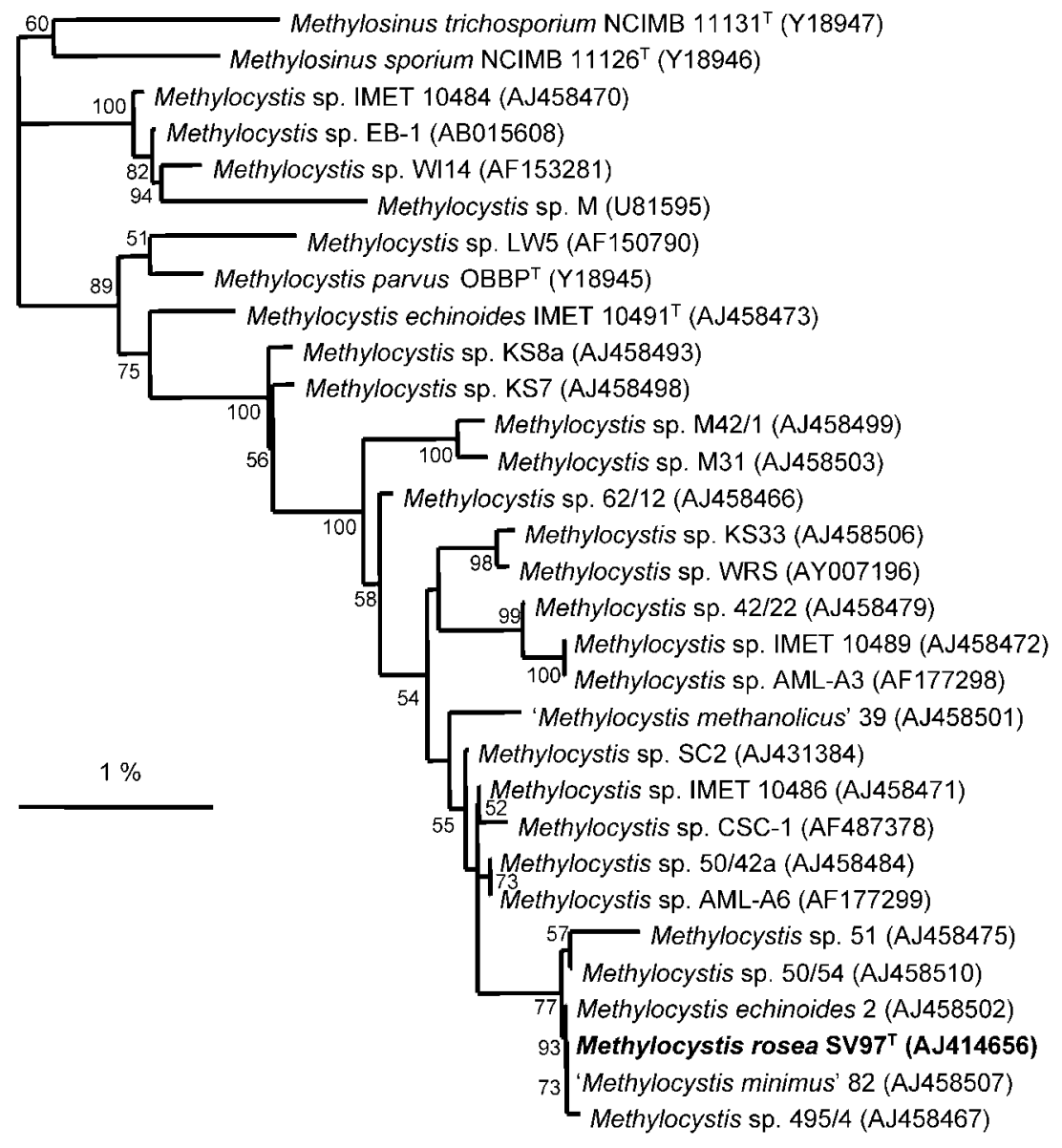

Fig. 1. Phylogenetic relationship of the $16 \mathrm{~S}$ rRNA gene sequences of Methylocystis rosea SV97 ${ }^{\top}$ and other Methylocystis strains and related genera. The dendrogram shows the results of an analysis in which DNADIST and neighbour-joining were used. Bootstrap values greater than $50 \%$, derived from 100 replicates, are also shown. Bar, $1 \%$ sequence divergence. 
was performed with Methylocystis parvus $\mathrm{OBBP}^{\mathrm{T}}$ and Methylocystis echinoides IMET $10491^{\mathrm{T}}$ according to Ezaki et al. (1989). The $16 \mathrm{~S}$ rRNA gene, soluble methane monooxygenase gene $(\mathrm{mmoX})$, small subunit of particulate methane monoxygenase gene $(p m o A)$ and nitrogenase reductase structural gene (nifH) were analysed by PCR as described previously (Fuse et al., 1998; Miguez et al., 1997).

Growth of strain $S V 97^{\mathrm{T}}$ was measured at temperatures ranging from 5 to $40{ }^{\circ} \mathrm{C}$, using a temperature gradient apparatus. Cultures of $\mathrm{SV} 97^{\mathrm{T}}$ were prepared by adding $5 \mathrm{ml}$ starting culture to $27 \mathrm{ml}$ serum bottles. The bottles were sealed with rubber stoppers and crimp caps before $5 \mathrm{ml}$ air was replaced with $5 \mathrm{ml} \mathrm{CH} / \mathrm{CO}_{2}$ (95:5) mix and the cultures were grown for 5 days. The $\mathrm{OD}_{600}$ was measured for the starting culture and for the 5-day-old cultures using a Spectramax 250 microplate spectrophotometer system (Molecular Devices). The maximum $\mathrm{OD}_{600}$ of strain $\mathrm{SV} 7^{\mathrm{T}}$ was $0 \cdot 7$ and was measured after 15 days at $20^{\circ} \mathrm{C}$. The experiment was repeated with three replicates at each temperature setting and net growth was calculated by subtracting the $\mathrm{OD}_{600}$ of the starting culture from the $\mathrm{OD}_{600}$ values of the 5 -day-old cultures. The mean values for net growth and standard deviations were calculated.
Phylogenetic analysis of the $16 \mathrm{~S}$ rRNA gene sequence was performed using the PHYLIP (Felsenstein, 1993) and TREEVIEW (Page, 1996) software packages after multiple alignment of data by CLUSTAL_X (Thompson et al., 1997). Distances (Kimura two-parameter model) and clustering by neighbour-joining methods were determined by using bootstrap values based on 100 replicates (Fig. 1). Phylogenetic analysis and alignment of $p m o A$ data were performed using the software package ARB (Ludwig et al., 2004) (Fig. 2).

The 16S rRNA gene sequence of strain $\mathrm{SV} 7^{\mathrm{T}}$ was a continuous stretch of $1438 \mathrm{bp}$. Sequence similarity calculations indicated that the closest relatives of strain $\mathrm{SV} 97^{\mathrm{T}}$ with validly published names were Methylocystis parvus $\mathrm{OBBP}^{\mathrm{T}}$ $(97 \cdot 2 \%)$ and Methylocystis echinoides IMET $10491^{\mathrm{T}}(97 \%)$. High sequence similarities were found with many noncharacterized strains of Methylocystis with GenBank accession nos AJ458507 and AJ458502 (100\%) and AF177299, AJ458510, AJ458467, AJ458471, AJ431384, AJ458475, AJ458484, AJ458501 and AJ458466 (99\%) (Table 1). Lower sequence similarity was found with members of the genus Methylosinus. Methylosinus sporium NCIMB $11126^{\mathrm{T}}$ and Methylosinus trichosporium OB3 $\mathrm{b}^{\mathrm{T}}$ both showed $96 \%$ sequence similarity to $\mathrm{SV} 97^{\mathrm{T}}$. Sequence similarity calculations

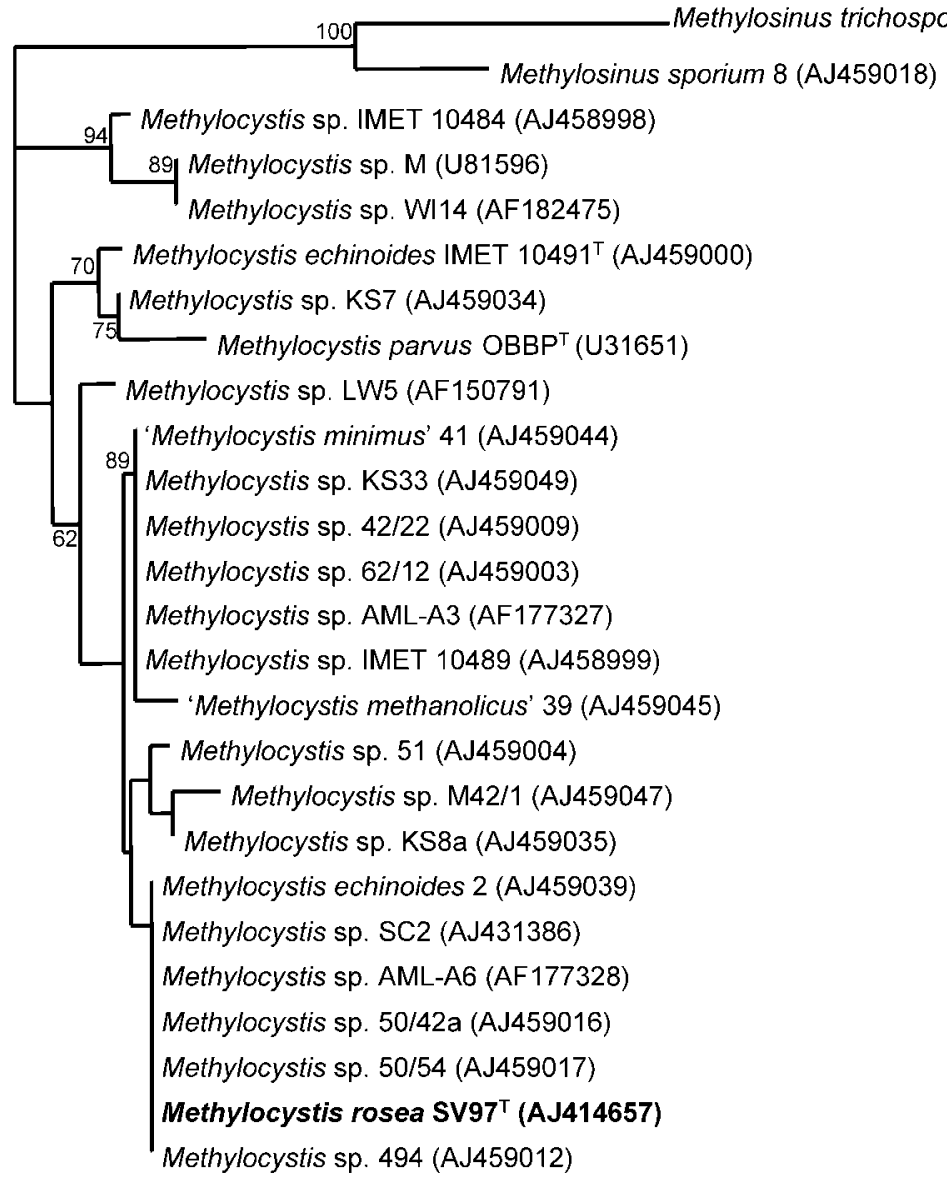

$10 \%$
Fig. 2. Phylogenetic relationship of the $p m o A$ sequences of Methylocystis rosea SV97 $^{\top}$ and other Methylocystis strains and related genera. The dendrogram shows the results of an analysis in which PROTDIST and neighbourjoining were used. Bootstrap values greater than $50 \%$, derived from 100 replicates, are also shown. Bar, $10 \%$ sequence divergence. 
indicated that the closest related nifH sequences were derived from Methylocystis echinoides IMET $10491^{\mathrm{T}}$ (97\%), 'Methylocystis minimus' INMI 41 (97\%) and Methylocella silvestris BL2 (91\%).

Cells of strain $\mathrm{SV} 97^{\mathrm{T}}$ were non-motile, $0 \cdot 8-1 \cdot 1 \mu \mathrm{m}$ wide and $1 \cdot 1-2 \cdot 5 \mu \mathrm{m}$ in length. Cells often appeared singly or in aggregates, but never in rosettes. Colonies were pink-red pigmented (Fig. 3). Strain $S V 97^{\mathrm{T}}$ grew at all $\mathrm{pH}$ values tested, from $5 \cdot 5$ to $9 \cdot 0$, and no exospores or cysts were revealed using the methods described. Strain $\mathrm{SV} 97^{\mathrm{T}}$ was obligately methane oxidizing; it did not grow on any of the alternative carbon sources tested. Strain $\mathrm{SV} 97^{\mathrm{T}}$ grew well on both NMS and AMS media and grew poorly on NFMS. The presence of nifH (Poly et al., 2001) indicates that strain $\mathrm{SV}^{\mathrm{T}}{ }^{\mathrm{T}}$ actively fixes nitrogen (Auman et al., 2001). A type II intracytoplasmic membrane structure, with pairwise membranes aligned parallel to the cell wall, was confirmed using transmission electron microscopy (Fig. 4). Staining with
Sudan black, phase-contrast microscopy and chemical analysis indicated the presence of PHB inclusions. The major phospholipid fatty acids for strain $\mathrm{SV} 7^{\mathrm{T}}$ were $\mathrm{C}_{18: 1} \omega 8(54 \cdot 2 \%), \mathrm{C}_{18: 1} \omega 7(39 \cdot 7 \%)$ and $\mathrm{C}_{16: 1} \omega 7(6 \cdot 1 \%)$. Details of the methods used for fatty acid analysis are available as Supplementary material in IJSEM Online. Isolate $\mathrm{SV}^{\mathrm{T}}{ }^{\mathrm{T}}$ had a DNA G $+\mathrm{C}$ content of $62 \mathrm{~mol} \%( \pm 1 \%)$. Strain $S V 97^{\mathrm{T}}$ tested negative for $m m o X$ in PCR assays and no sMMO was detected by the colorimetric assay. Isolate $\mathrm{SV} 97^{\mathrm{T}}$ had an optimum growth temperature of $27^{\circ} \mathrm{C}$, but grew well at temperatures from 14 to $37^{\circ} \mathrm{C}$ (see Supplementary Fig. S1 in IJSEM Online). DNA-DNA hybridization between strain $\mathrm{SV}^{\mathrm{T}}{ }^{\mathrm{T}}$ and Methylocystis parvus $\mathrm{OBBP}^{\mathrm{T}}$ and Methylocystis echinoides IMET $10491^{\mathrm{T}}$ revealed 11 and $12 \%$ DNA-DNA relatedness, respectively. Strain $S V 97^{\mathrm{T}}$ differs from M. parvus $\mathrm{OBBP}^{\mathrm{T}}$ in several phenotypic and genotypic characteristics; it does not have coccibacillus-shaped cells but has rodshaped cells, does not produce cysts, has pink-redpigmented cells, has no urease activity, has a lower DNA

Table 1. 16S rRNA gene sequence similarities of Methylocystis isolates compared with strain SV97 ${ }^{\top}$

Unusual phenotypes of strains and the presence of $m m o X$ are included. Strain $S V 97^{\mathrm{T}}$ shows $97 \%$ gene sequence similarity to $M$. echinoides IMET $10491^{\mathrm{T}}$ and $M$. parvus $\mathrm{OBBP}^{\mathrm{T}}$. The GenBank accession numbers of the strains are shown in Fig. 1. +, Positive; - , negative; ND, not determined.

\begin{tabular}{|c|c|c|c|c|c|}
\hline Strain & $\begin{array}{l}\text { Number of } \\
\text { nucleotides }\end{array}$ & $\begin{array}{l}\text { Similarity } \\
(\%)\end{array}$ & $\operatorname{mmoX}$ & $\begin{array}{c}\text { Unusual } \\
\text { phenotypes }\end{array}$ & Reference \\
\hline M. rosea $\mathrm{SV} 7^{\mathrm{T}}$ & 1438 & - & - & Dark pink & This study \\
\hline 'Methylocystis minimus' 82 & 1407 & 100 & + & & Heyer et al. (2002) \\
\hline Methylocystis sp. AML-A6 & 1431 & 99 & - & White, coccus & Wise et al. (1999) \\
\hline Methylocystis sp. 50/54 & 1402 & 99 & + & & Heyer et al. (2002) \\
\hline Methylocystis sp. CSC-1 & 1422 & 99 & ND & & $\begin{array}{l}\text { D. Hudson, I. Uz, A. V. Ogram } \\
\text { and A. S. Lindner (unpublished) }\end{array}$ \\
\hline Methylocystis sp. IMET 10486 & 1406 & 99 & + & & Heyer et al. (2002) \\
\hline Methylocystis sp. SC2 & 1409 & 99 & - & White & Dunfield et al. (2002) \\
\hline Methylocystis sp. 51 & 1402 & 99 & + & & Heyer et al. (2002) \\
\hline Methylocystis sp. AML-A3 & 1462 & 98 & - & Pink, coccus & Wise et al. (1999) \\
\hline Methylocystis sp. KS33 & 1405 & 98 & - & Coccoid & Heyer et al. (2002) \\
\hline Methylocystis sp. $42 / 22$ & 1408 & 98 & - & & Heyer et al. (2002) \\
\hline Methylocystis sp. IMET 10489 & 1404 & 98 & - & & Heyer et al. (2002) \\
\hline Methylocystis sp. M31 & 1407 & 98 & - & & Heyer et al. (2002) \\
\hline Methylocystis sp. M42/1 & 1401 & 98 & - & & Heyer et al. (2002) \\
\hline Methylocystis sp. KS7 & 1407 & 98 & - & $\begin{array}{l}\text { Large coccus and } \\
\text { rods, motile }\end{array}$ & Heyer et al. (2002) \\
\hline Methylocystis sp. KS8a & 1406 & 98 & - & $\begin{array}{l}\text { Coccoid and bent } \\
\text { rods, motile }\end{array}$ & Heyer et al. (2002) \\
\hline
\end{tabular}




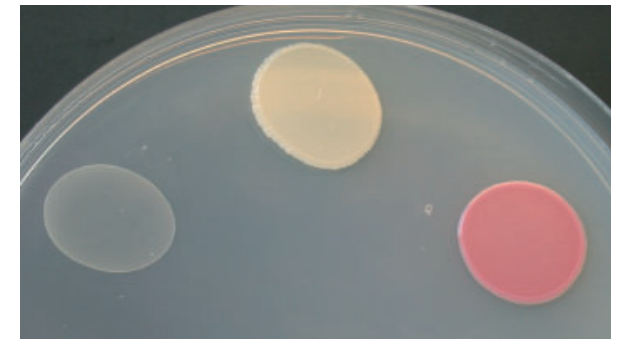

Fig. 3. Differences in pigmentation between $M$. echinoides IMET $10491^{\top}$ (left), M. parvus $\mathrm{OBBP}^{\top}$ (middle) and M. rosea SV $97^{\top}$ (right), grown on the same NMS agar plate.

$\mathrm{G}+\mathrm{C}$ content $(62 \mathrm{~mol} \%)$ and shows $11 \%$ DNA-DNA hybridization and $97 \cdot 2 \% 16 \mathrm{~S}$ rRNA gene sequence similarity. Strain SV97 ${ }^{\mathrm{T}}$ differs from Methylocystis echinoides IMET $10491^{\mathrm{T}}$ in that it does not have coccibacillus-shaped cells, does not show spinae, has pink-red-pigmented cells, grows at $\mathrm{pH} 5.5$ and $9 \cdot 0$, produces $\mathrm{PHB}$ and shows only $12 \%$ DNA-DNA hybridization and $97 \%$ 16S rRNA gene sequence similarity. These differences are summarized in Table 2.

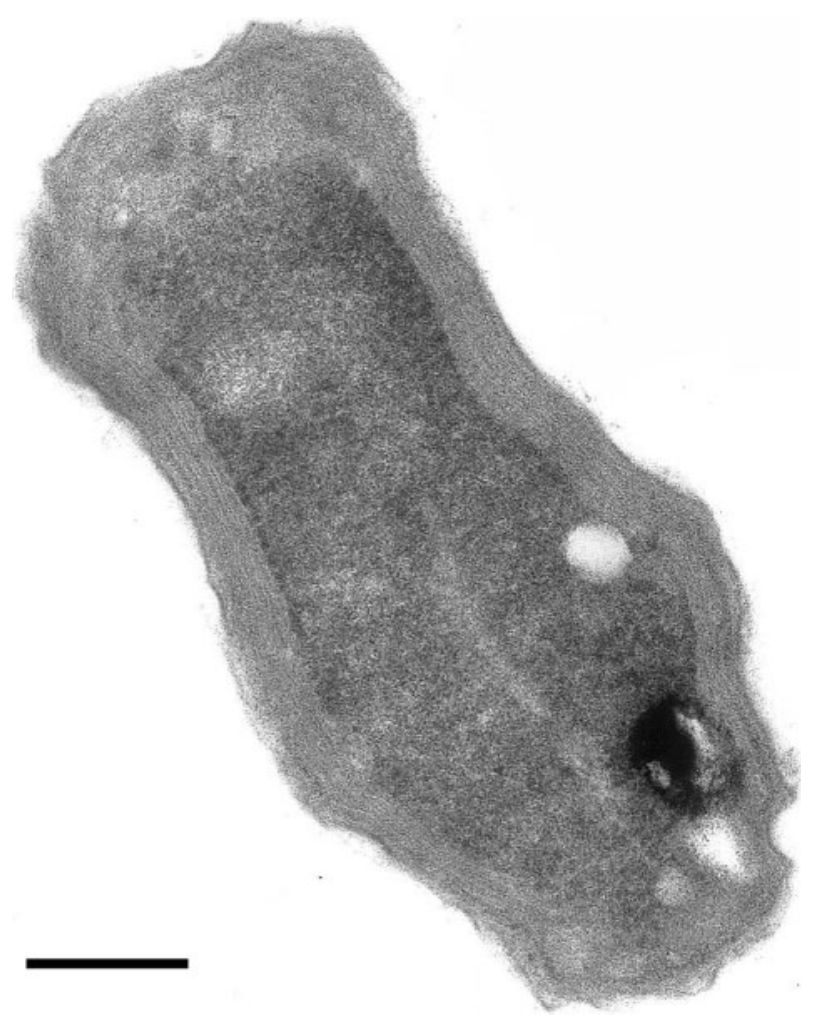

Fig. 4. Transmission electron micrograph of a cell of strain SV97 ${ }^{\top}$ showing the type II intracytoplasmic membranes aligned with the periphery of the cell and inclusions (white spot). Bar, $200 \mathrm{~nm}$.
Strain $\mathrm{SV}^{\mathrm{T}}{ }^{\mathrm{T}}$ groups very closely with a number of Methylocystis isolates which have not been fully characterized (Methylocystis spp. 51, 50/54, 495/4, 'Methylocystis minimus' 82 and Methylocystis echinoides 2) (Fig. 1) and which were isolated from a variety of different environments, including Baltic coast sediment, soil near an oil extraction plant and bog water (Heyer et al., 2002). From the data available (Table 1), it can be seen that none of these strains, with the exception of $\mathrm{SV} 97^{\mathrm{T}}$, are pink pigmented. One strain, Methylocystis echinoides 2 (Galchenko et al., 1977), has spinae, the other four strains have no particular distinguishing phenotype, but are all $m m o X$-positive. These strains may well be representatives of the same species as $\mathrm{SV} 97^{\mathrm{T}}$, but this would need to be confirmed by further characterization and DNADNA hybridization studies. In view of the phenotypic and genotypic differences between strain $\mathrm{SV} 97^{\mathrm{T}}$ and the other Methylocystis type species (including 16S rRNA gene sequences, DNA-DNA hybridization and phenotypic characteristics), we propose that strain $\mathrm{SV} 97^{\mathrm{T}}$, isolated from wetland soil from the Svalbard Islands, Norway, represents a novel species with the name Methylocystis rosea sp. nov.

According to Rule 65 (2) of the Bacteriological Code (Lapage et al., 1992), the genus Methylocystis is incorrectly in

Table 2. Characteristics that distinguish Methylocystis rosea SV97 ${ }^{\top}$ from other type strains of the genus Methylocystis

Species: 1, M. rosea SV97 ${ }^{\mathrm{T}}$; 2, M. echinoides IMET 10491 ${ }^{\mathrm{T}}$; 3, M. parvus $\mathrm{OBBP}^{\mathrm{T}}$. Data for $M$. echinoides IMET $10491^{\mathrm{T}}$ and $M$. parvus $\mathrm{OBBP}^{\mathrm{T}}$ are from Bowman et al. (1993). All type strains of the genus Methylocystis have reniform or vibrioid cell morphology, type II membranes, are non-motile, grow at $28^{\circ} \mathrm{C}$, assimilate carbon via the serine pathway, are oxidase-positive, contain the

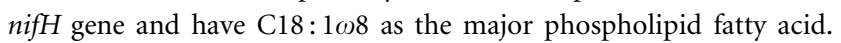

\begin{tabular}{|c|c|c|c|}
\hline Characteristic & 1 & 2 & 3 \\
\hline \multicolumn{4}{|l|}{ Cell morphology: } \\
\hline Coccibacilli & - & + & + \\
\hline Rods & + & + & - \\
\hline Spinae & - & + & - \\
\hline Cyst formation & - & - & + \\
\hline \multicolumn{4}{|l|}{ Pigmentation: } \\
\hline White or buff & - & + & - \\
\hline Diffusible brown & - & - & + \\
\hline Pale pink & - & - & + \\
\hline Pink-red & + & - & - \\
\hline \multicolumn{4}{|l|}{ Growth at: } \\
\hline $37^{\circ} \mathrm{C}$ & + & - & + \\
\hline $\mathrm{pH} 9 \cdot 0$ & + & - & + \\
\hline $\mathrm{pH} 5 \cdot 0$ & + & - & + \\
\hline \multicolumn{4}{|l|}{ Biochemistry: } \\
\hline PHB & + & - & + \\
\hline Urease & - & - & + \\
\hline DNA G $+\mathrm{C}$ content $(\mathrm{mol} \%)$ & 62 & 62 & $64-67$ \\
\hline DNA-DNA hybridization with SV97 ${ }^{\mathrm{T}}$ & $(100 \%)$ & $12 \%$ & $11 \%$ \\
\hline
\end{tabular}


the masculine gender. As the Greek noun kustis is in the feminine gender, the Neo-Latin name Methylocystis should also be in the feminine gender. In turn, the specific epithet of the type species, Methylocystis parvus, should correctly be parva. The specific epithet echinoides [Methylocystis echinoides (Bowman et al., 1993; Galchenko et al., 1977)] is correct, but is a Neo-Latin feminine adjective.

\section{Description of Methylocystis rosea sp. nov.}

Methylocystis rosea (ro'se.a. L. fem. adj. rosea rose-coloured, rosy).

Cells are Gram-negative, polymorphic, straight or curved fat rods, $1 \cdot 1-2 \cdot 5 \mu \mathrm{m}$ long and $0 \cdot 8-1 \cdot 1 \mu \mathrm{m}$ wide. Colonies on NMS agar plates are pink-red pigmented. Cells occur singly or in shapeless aggregates, but do not form rosettes when observed by light microscopy. The cells are non-motile and possess a type II intracellular membrane system. Cells do not possess sMMO, but have nifH. Cells are catalase-positive. Grows at temperatures from 5 to $37^{\circ} \mathrm{C}$. Optimal growth occurs at $27^{\circ} \mathrm{C}$, no growth occurs at $40^{\circ} \mathrm{C}$. Does not require $\mathrm{NaCl}$ for growth and cells are not lysed by $2 \%$ SDS. Grows well at $\mathrm{pH}$ from $5 \cdot 5$ to $9 \cdot 0$. Phospholipid fatty acids are $\mathrm{C}_{18: 1} \omega 8(54 \cdot 2 \%), \mathrm{C}_{18: 1} \omega 7(39 \cdot 7 \%)$ and $\mathrm{C}_{16: 1} \omega 7(6 \cdot 1 \%)$. No exospores or cysts have been revealed. Accumulates PHB. The DNA G $+\mathrm{C}$ content is $62 \mathrm{~mol} \%$. The type strain shows DNA-DNA hybridization values of 11 and $12 \%$, respectively, to Methylocystis parvus $\mathrm{OBBP}^{\mathrm{T}}$ and Methylocystis echinoides IMET $10491^{\mathrm{T}}$.

The type strain, $\operatorname{SV}^{\mathrm{T}}\left(=\right.$ ATCC BAA- $1196^{\mathrm{T}}=$ DSM $\left.17261^{\mathrm{T}}\right)$, was isolated from a high Arctic wetland soil near $\mathrm{Ny}$ Ålesund, Svalbard Islands, Norway.

\section{Acknowledgements}

We thank Frida Lise Daae (Institute of Biology, University of Bergen) for determination of DNA G+C content and Espen Hansen (Department of Biology, University of Tromsø) for the fatty acid analyses. We thank the Norwegian Research Council for financial support (grant 121458/720), the Norwegian Polar Institute for economic support to field work and UNIS (University Courses on Svalbard) for access to laboratory facilities. We also thank Dr John Bowman for helpful discussions.

\section{References}

Auman, A. J., Speake, C. C. \& Lidstrom, M. E. (2001). nifH sequences and nitrogen fixation in type I and type II methanotrophs. Appl Environ Microbiol 67, 4009-4016.

Bowman, J. P., Sly, L. I., Nichols, P. D. \& Hayward, A. C. (1993). Revised taxonomy of the methanotrophs: description of Methylobacter gen. nov., emendation of Methylococcus, validation of Methylosinus and Methylocystis species, and a proposal that the family Methylococcaceae includes only the group I methanotrophs. Int J Syst Bacteriol 43, 735-753.

Brusseau, G. A., Tsien, H. C., Hanson, R. S. \& Wackett, L. P. (1990). Optimization of trichloroethylene oxidation by methanotrophs and the use of a colorimetric assay to detect soluble methane monooxygenase activity. Biodegradation 1, 19-29.

Dedysh, S. N., Liesack, W., Khmelenina, V. N., Suzina, N. E., Trotsenko, Y. A., Semrau, J. D., Bares, A. M., Panikov, N. S. \& Tiedje, J. M. (2000). Methylocella palustris gen. nov., sp. nov., a new methane-oxidizing acidophilic bacterium from peat bogs, representing a novel subtype of serine-pathway methanotrophs. Int J Syst Evol Microbiol 50, 955-969.

Dedysh, S. N., Khmelenina, V. N., Suzina, N. E., Trotsenko, Y. A., Semrau, J. D., Liesack, W. \& Tiedje, J. M. (2002). Methylocapsa acidiphila gen. nov., sp. nov., a novel methane-oxidizing and dinitrogen-fixing acidophilic bacterium from Sphagnum bog. Int J Syst Evol Microbiol 52, 251-261.

Dunfield, P. F., Yimga, M. T., Dedysh, S. N., Berger, U., Liesack, W. \& Heyer, J. (2002). Isolation of a Methylocystis strain containing a novel pmoA-like gene. FEMS Microbiol Ecol 41, 17-26.

Ezaki, T., Hashimoto, Y. \& Yabuuchi, E. (1989). Fluorimetric deoxyribonucleic acid-deoxyribonucleic acid hybridization in microdilution wells as an alternative to membrane filter hybridization in which radioisotopes are used to determine genetic relatedness among bacterial strains. Int J Syst Bacteriol 39, 224-229.

Felsenstein, J. (1993). PHYLIP - phylogenetic interference package, version 3.5c. Distributed by the author. Department of Genome Sciences, University of Washington, Seattle, USA.

Fuse, H., Ohta, M., Takimura, O., Murakami, K., Inoue, H., Yamaoka, Y., Oclarit, J. M. \& Omori, T. (1998). Oxidation of trichloroethylene and dimethyl sulfide by a marine Methylomicrobium strain containing soluble methane monooxygenase. Biosci Biotechnol Biochem 62, 1925-1931.

Galchenko, V. F., Shiskina, V. N., Suzina, N. E. \& Trotsenko, Y. A. (1977). Isolation and properties of new strains of obligate methanotrophs. Mikrobiologiia 46, 723-728.

Gerhardt, P. (1981). Manual of Methods for General Bacteriology. Washington, DC: American Society for Microbiology.

Graham, D. W., Korich, D. G., LeBlanc, R. P., Sinclair, N. A. \& Arnold, R. G. (1992). Applications of a colorimetric plate assay for soluble methane monooxygenase activity. Appl Environ Microbiol 58, 2231-2236.

Hanson, R. S. \& Hanson, T. E. (1996). Methanotrophic bacteria. Microbiol Rev 60, 439-471.

Heyer, J., Galchenko, V. F. \& Dunfield, P. F. (2002). Molecular phylogeny of type II methane-oxidizing bacteria isolated from various environments. Microbiology 148, 2831-2846.

Høj, L., Olsen, R. A. \& Torsvik, V. L. (2005). Archaeal communities in high Arctic wetlands at Spitsbergen, Norway $\left(78^{\circ} \mathrm{N}\right)$ as characterized by $16 \mathrm{~S}$ rRNA gene fingerprinting. FEMS Microbiol Ecol 53, 89-101.

Lapage, S. P., Sneath, P. H. A., Lessel, E. F., Skerman, V. B. D., Seeliger, H. P. R. \& Clark, W. A. (editors) (1992). International Code of Nomenclature of Bacteria (1990 Revision). Bacteriological Code. Washington, DC: American Society for Microbiology.

Ludwig, W., Strunk, O., Westram, R. \& 29 other authors (2004). ARB: a software environment for sequence data. Nucleic Acids Res 32, 1363-1371.

Mandel, M., Igambi, L., Bergendahl, J., Dodson, M. L., Jr \& Scheltgen, E. (1970). Correlation of melting temperature and cesium chloride buoyant density of bacterial deoxyribonucleic acid. J Bacteriol 101, 333-338.

Miguez, C. B., Bourque, D., Sealy, J. A., Greer, C. W. \& Groleau, D. (1997). Detection and isolation of methanotrophic bacteria possessing soluble methane monooxygenase ( $\mathrm{sMMO}$ ) genes using the polymerase chain reaction (PCR). Microb Ecol 33, 21-31. 
Page, R. D. M. (1996). TreeView: an application to display phylogenetic trees on personal computers. Comput Appl Biosci 12, 357-358.

Poly, F., Monrozier, L. J. \& Bally, R. (2001). Improvement in the RFLP procedure for studying the diversity of nifH genes in communities of nitrogen fixers in soil. Res Microbiol 152, 95-103.

Thompson, J. D., Gibson, T. J., Plewniak, F., Jeanmougin, F. \& Higgins, D. G. (1997). The CLUSTAL_X windows interface: flexible strategies for multiple sequence alignment aided by quality analysis tools. Nucleic Acids Res 25, 4876-4882.
Vela, G. R. \& Wyss, O. (1964). Improved stain for visualization of Azotobacter encystment. J Bacteriol 87, 476-477.

Whittenbury, R., Phillips, K. C. \& Wilkinson, J. F. (1970). Enrichment, isolation and some properties of methane-utilizing bacteria. J Gen Microbiol 61, 205-218.

Wise, M. G., McArthur, J. V. \& Shimkets, L. J. (1999). Methanotroph diversity in landfill soil: isolation of novel type I and type II methanotrophs whose presence was suggested by culture-independent $16 \mathrm{~S}$ ribosomal DNA analysis. Appl Environ Microbiol 65, 4887-4897. 